\title{
Plant polytene chromosomes
}

\author{
Gianna Maria Griz Carvalheira
}

Laboratório de Citogenética Vegetal, Área de Genética, Departamento de Biologia, UFRPE, 52171-030 Recife, PE, Brasil. E-mail: carva@elogica.com.br

\section{INTRODUCTION}

Polytene chromosomes are structures found in highly specialized tissues in some animal and plant species, which are amplified through successive cycles of endoreduplication, finally producing several copies of each chromosome. For this reason, they have been very important in elucidating chromosome fine structure and physiology, especially in diptera.

In plants, polytene chromosomes have been observed in only a few species, and seemed to be restricted to ovary and immature seed tissues, e.g., in Phaseolus coccineus and $P$. vulgaris (Nagl, 1981), until relatively recently, when they were observed in the cells of the anther tapetum of Vigna unguiculata (Guerra and Carvalheira, 1994) and of some Phaseolus species (Carvalheira and Guerra, 1994). With the discovery of the polytenics in tapetum tissue, it was observed that in many other species of various angiosperm families the tapetal cells also display polytene, polyploid or both types of nuclei. In some species of Phaseolus and Vigna the polytenics are more clearly defined and, therefore, better suited to the study of this type of chromatin organization. It is, however, important to differentiate between the nuclear cycles that result in polyploid nuclei and those that produce polytene nuclei, because these two terms of the nuclear types are often used indiscriminately in the literature. In this paper some aspects of the occurrence of plant polytenes will be summarized along with the structure and function of these chromosomes.

\section{ENDOMITOSIS AND ENDOREDUPLICATION}

Nagl et al. (1985) described polytene chromosomes as giant chromosomes produced by changes in the mitotic cycle during the interphase stage. In such a modified nuclear cycle, the chromatin duplicates its DNA content during the $G_{1}$ and $S$ stages, but, instead of passing to the $G_{2}$ stage, the nucleus initiates a new $\mathrm{G}_{1}$ phase, thus starting a new cycle of chromatin duplication. This type of cycle was first described in 1939 by Geitler, as occurring in the somatic cells of the insect Gerris lateralis (Painter and Reindorp, 1939; D'Amato, 1964), and was named the "endomitotic cycle" because it develops within the nuclear envelop without either achromatic spindle formation or nuclear or cellular division (Nagl, 1970a; Brodsky and
Uryvaeva, 1985). The term endomitosis is, however, generally used to describe the formation of both polyploid and polytene nuclei (q.v. Nagl, 1974). $\operatorname{Nagl}(1978,1981,1987)$ has suggested the term endocycle rather than endomitosis, and D'Amato (1984) has adopted the term endomitotic and endoreduplication to distinguish between those that produce polyploid and polytene nuclei, respectively.

The endomitotic cycle (endomitosis) starts with a normal prophase (endoprophase), after which the chromosome contracts further (endometaphase), their sister chromatids separate from each other (endoanaphase) and decondense to assume the interphase nuclear structure, resulting in polyploid cells, with double the chromosome number (endopolyploidy) at the end of each cycle. The essential difference between endomitosis and the normal cell cycle is the absence of nuclear membrane dissolution in endomitosis, with the whole cycle occurring inside the nucleus. Such cycles have been observed in the anther tapetum of some angiosperm species, as in some Passiflora species and in Papaver rhoeas (Figure 1a).

The endoreduplication cycle differs from endomitosis because it results in polytene cells (cells with many identical paired chromatids). In the endoreduplication cycle, the chromatid number is duplicated, but they do not segregate, and after various endoreduplication cycles, larger and thicker chromosomes are produced, called polytenics. In the endoreduplication cycle, the condensation and decondensation stages are not evident (D'Amato 1984, 1989), except in some cells where it is possible to see the chromocenter dispersion phase, known as the Z-phase (Nagl, 1970b, 1972; Cavallini et al., 1981).

Depending on the behavior of the sister chromatids, polytene nuclei can be divided into two structural types. The first, and most well studied, are the chromosomes of the larval cells of Drosophila, Chironomidae and other diptera (Ashburner, 1970; Brodsky and Uryvaeva, 1985). These polytenics are characterized by numerous transverse bands along their linear axis, produced by the exact pairing of sister chromatids and the intimate association of their chromomeres (Ashburner, 1970). The somatic pairing of homologous chromosomes gives the false impression that there has been a decrease in chromosome number, because each nucleus appears to contain the haploid number of giant chromosomes.

The other structural type of polytene nuclei also has 
the grouping of sister chromatid bundles resulting from several endoreduplication cycles, but in this case is characterized by the lack of any intimate pairing of the chromatids (Figure 1b). This nucleus type is observed more frequently, typical examples being found in the giant trophoblast cells of mammals (Nagl, 1985), the trophocit cells of many insects (Painter and Reindorp, 1939), some ovary tissues during the development of many angiosperms (Corsi et al., 1973; Nagl, 1976) and in the anther tapetum of some plant species (D'Amato, 1984; Guerra and Carvalheira, 1994; Carvalheira and Guerra, 1994, 1998). In these nuclei, which can be recognized both by the large size of their chromocenters and by the diploid number of polytene chro- mosomes, the chromosome number does not appear to be reduced as in polytene-type nuclei. Another peculiar giant chromosome type, which likewise does not present somatic pairing, has been found in some ciliates (e.g., Stylonychia mytilus) that have a macronucleus with polytene chromosomes and a diploid micronucleus (Ammermann, 1971; Ammermann et al., 1974). The polytenics of these ciliates display band and interband patterns (also seen in Drosophila), but the macronucleus disintegrates after its development while the micronucleus remains active.

It is interesting to note that the endocycles are not processes of cell multiplication but are associated with cell differentiation and seem to be genetically controlled, with

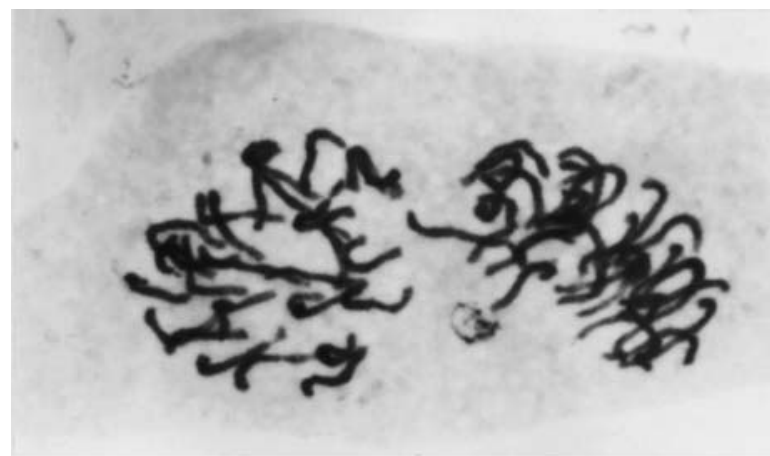

a
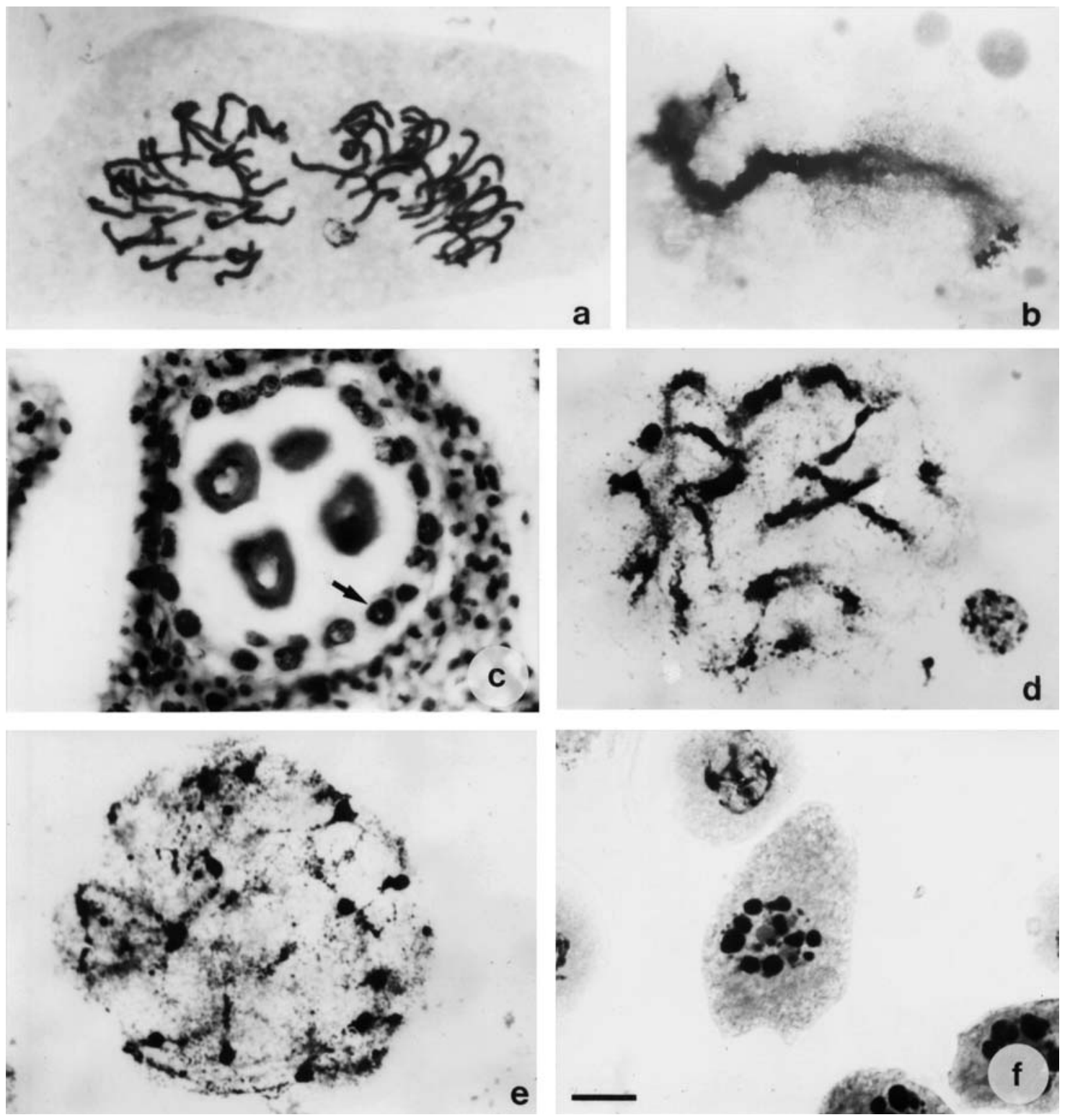

Figure 1 - a) Binucleate tapetal cell of Papaver rhoeas; b) C-banding in polytene chromosome of Phaseolus coccineus suspensor (Courtesy of Dr. D. Schweizer); c) transversal section of Vigna unguiculata anther with meiocytes (arrow shows tapetal nucleus); d) tapetal nucleus of Vigna unguiculata showing polytene chromosomes (compare with diploid nucleus); e) tapetal polytene nucleus of Phaseolus acutifolius showing chromocenters-associated thinner chromatin bundles; f) mononucleate tapetal cell of Genipa americana showing chromocenters without chromatids bundled. Bar scale represents $10 \mu \mathrm{m}$, except to $\mathbf{b}$ and $\mathbf{c}$. 
both endopolyploidy and polyteny leading to cell specialization in certain tissues. These nuclei have generally been observed in ephemeral tissues made up of only a few cells with intense metabolic activity, the main function of which is to provide nutritional support to vital organs during certain periods of development (e.g., the larval salivary glands of insects, the mammalian trophoblasts and the embryo suspensor cells of angiosperms). In such tissues, the cytoplasmatic volume and nuclei DNA content of the cells are increased by endomitosis or endoreduplication cycles (Nagl, 1974, 1985; Nagl et al., 1985).

\section{OCCURRENCE OF POLYTENE CHROMOSOMES}

Polytene nuclei were first observed in the larval salivary glands of Chironomidae, by Balbiani in 1881, but only at the beginning of the 1930s did Heitz and Bauer \& Painter, independently and simultaneously, rediscover these enormous nuclei in the Malpighian tubules of Bibio hortulanus and in the larval salivary glands of Drosophila melanogaster, respectively (Ashburner, 1970). A few years later, Koltzoff, in 1934, and Bauer, in 1935, proposed the term polytenics for the giant chromosomes observed in these nuclei (Ashburner, 1970); polytene cells have since been described in many species (Nagl, 1978; Brodsky and Uryvaeva, 1985; Carvalheira and Guerra, 1998).

In plants, the first giant nuclei were observed by Osterwalder in 1898, in the enormous antipodal cells (antipodes) of the embryo sac of Aconitum (Nagl, 1981). However, as with the discovery of the giant cells of Chironomidae, the antipodal nuclei were largely forgotten for about 60 years. Only in 1956 did Tschermack-Woess and collaborators, during a reappraisal of the genus Aconitum genus and other plant species, recognize that the chromosomes observed in the antipodes were polytenics (Nagl, 1981). Unlike Drosophila polytene chromosomes, which present numerous bands and interbands, plant polytenics have a granular and fibril structure with no distinct bands (see Figure 1). This structure probably occurs because of the absence of intimate synapsis between the sister chromatids. It is also believed that the chromocenter dispersion phase ( $Z$ phase) has some influence on the morphology of plant polytenics, as it results in a slight separation of these chromatids (Nagl, 1970a). However, Nagl (1969a) has reported that in Phaseolus vulgaris the structure of polytene chromosomes of embryo suspensor cells seems to be altered when these cells are submitted to low temperatures, becoming partly compacted and forming bands similar to those seen in Drosophila. Such results have not been observed again, remaining the only report of plant polytenics with bands and interbands.

Since the discovery of the polytene nuclei in antipodes, many other tissues composed of polytene cells have also been described (Table I). It is interesting to note that, until very recently, the cells with polytene chromosomes seemed to be limited to ovary tissues (antipodal cells, syn- ergids, endosperm and embryo suspensor cells); however, polytenics have now been observed in anther hair, glandular hair and anther tapetal cells (Table I).

Polyteny can also be induced in vitro and it has been found that the meristematic tissues of root tips and the cotyledon cells of some plant species are able to form polytene chromosomes when submitted to specific treatments, including high temperatures (Shang and Wang, 1991) or an appropriate amount of certain growth regulators (mainly auxin and cytocinin) in the medium (Marks and Davies, 1979; Therman and Murashige, 1984).

\section{POLYTENE CHROMOSOMES OF EMBRYO SUSPENSOR}

The most widely studied plant tissues with polytene cells is the Phaseolus embryo suspensor tissue. This tissue is found in the developing ovary of several angiosperm species (Esau, 1974). In $P$. coccineus and $P$. vulgaris, the suspensor is composed of about 200 cells, distributed between the basal and junction regions. The basal region is formed of about 20 giant mononucleate cells with a high level of polytenization, and with the DNA content of some cells being up to $8.192 \mathrm{C}$ (Brady, 1973a,b). The junction region is composed of about 180 cells linking the basal region to the embryo proper. This last region possesses polyploid cells and/or cells with low polyteny level (Brady and Clutter, 1974).

The embryo suspensor provides nutritional support for the immature embryo, supplying proteins or synthesizing the substances necessary for embryo development (Schulz and Jensen, 1969). The underdevelopment of the cell wall of suspensor cells and their other structural characteristics indicate their secretory function in transporting nutrients through their membranes to the embryo (Nagl, 1974; Cionini, 1987). Analyses of the growth regulator level and transcription activity indicate that the suspensor tissue may play an important role during embryo ontogenesis, and seems to have a function in the synthesis of phytohormones needed for embryo development (Walbot et al., 1972; Clutter et al., 1974; Alpi et al., 1975; Cionini et al., 1976; Lorenzi et al., 1978).

The basal cells of the embryo suspensor tissue of $P$. coccineus display 22 polytene chromosomes that are up to 30 times larger than the mitotic ones (Nagl, 1974), the 11 chromosome pairs having been identified earlier by their heteropycnosis pattern (Nagl, 1967). All mitotic chromosomes present heterochromatic centromeric bands and some weak interstitial and terminal ones (Schweizer and Ambros, 1979). Staining with the fluorochromes CMA and DAPI has revealed that most of these bands are $\mathrm{CMA}^{+}$, although unlike mitotic bands they contain a small amount of DAPI ${ }^{+}$heterochromatin (Schweizer, 1976). The difference observed in the fluorescent pattern has been attributed to the better structural resolution of the giant chromosomes. 
Table I - Occurrence of polytene chromosomes in plants.

\begin{tabular}{|c|c|c|}
\hline Tissue & Species & References \\
\hline \multirow[t]{3}{*}{ Antipodes } & Aconitum neomontanum & Nagl, 1981 \\
\hline & Clivia miniata & Nagl, 1981 \\
\hline & Scilla bifolia & Nagl, 1976 \\
\hline \multirow[t]{3}{*}{ Endosperm } & Phlomis viscosa & Enzenberg, 1961 \\
\hline & Rhinanthus alectrophus & Nagl, 1981 \\
\hline & Thesium alpinum & Nagl, 1981 \\
\hline Anther hair & Bryonia dioica & Nagl, 1981 \\
\hline Glandular hair & Salvia horminum & Gostev and Asker, 1978 \\
\hline Synergids & Allium ursinum & Nagl, 1978 \\
\hline \multirow[t]{14}{*}{ Embryo suspensor } & Brassica nigra & Viegi et al., 1976 \\
\hline & Eruca sativa & Corsi, 1972; Corsi et al., 1973 \\
\hline & Gagea lutea & Nagl, 1981 \\
\hline & Lotus carmeli & Freed and Grant, 1976 \\
\hline & L. pedunculatus & Freed and Grant, 1976 \\
\hline & L. pursbianus & Freed and Grant, 1976 \\
\hline & Phaseolus cafter & Nagl, 1981 \\
\hline & P. coccineus & Clutter and Sussex, 1969 \\
\hline & P. hysterinus & Nagl, 1974 \\
\hline & P. multiflorus & Nagl, 1974 \\
\hline & P. tuberosus & Nagl, 1974 \\
\hline & P. vulgaris & Nagl, 1969b,c \\
\hline & Psophocarpus tetragonolobus & Sen, 1980 \\
\hline & Tropaeolum majus & Nagl, 1981 \\
\hline \multirow[t]{28}{*}{ Anther tapetum } & Arachis hypogeae & Carvalheira, G.M.G. and Guerra, M., unpublished data \\
\hline & Caesalpinia echinata & Carvalheira, G.M.G. and Guerra, M., unpublished data \\
\hline & Clitoria cajanifolia & Carvalheira, G.M.G. and Guerra, M., unpublished data \\
\hline & Crotalaria retusa & Carvalheira, G.M.G. and Guerra, M., unpublished data \\
\hline & Genipa americana & Carvalheira, G.M.G. and Guerra, M., unpublished data \\
\hline & Habenaria hexaptera & Carvalheira, G.M.G. and Guerra, M., unpublished data \\
\hline & H. obtusa & Carvalheira, G.M.G. and Guerra, M., unpublished data \\
\hline & H. repens & Carvalheira, G.M.G. and Guerra, M., unpublished data \\
\hline & Indigofora hirsuta & Carvalheira, G.M.G. and Guerra, M., unpublished data \\
\hline & Lathyrus sp. & Carvalheira, G.M.G. and Guerra, M., unpublished data \\
\hline & Lupinus polyphyllus & Carvalheira, G.M.G. and Guerra, M., unpublished data \\
\hline & Luffa cylindrica & Carvalheira, G.M.G. and Guerra, M., unpublished data \\
\hline & Macroptilium peduncularis & Carvalheira, G.M.G. and Guerra, M., unpublished data \\
\hline & Phaseolus acutifolius & Carvalheira and Guerra, 1994 \\
\hline & Phaseolus coccienus & Carvalheira and Guerra, 1994 \\
\hline & Phaseolus lunatus & Carvalheira and Guerra, 1994 \\
\hline & Phaseolus microcarpus & Carvalheira and Guerra, 1994 \\
\hline & Pithecellobium dulce & Carvalheira, G.M.G. and Guerra, M., unpublished data \\
\hline & Pisum sativum & Carvalheira, G.M.G. and Guerra, M., unpublished data \\
\hline & Sesbania marginata & Carvalheira, G.M.G. and Guerra, M., unpublished data \\
\hline & Sophora tomentosa & Carvalheira, G.M.G. and Guerra, M., unpublished data \\
\hline & Tropaeolum majus & Carvalheira, G.M.G. and Guerra, M., unpublished data \\
\hline & Vicia $\mathrm{sp}$. & Carvalheira, G.M.G. and Guerra, M., unpublished data \\
\hline & Vigna radiata & Carvalheira and Guerra, 1998 \\
\hline & Vigna umbellata & Carvalheira and Guerra, 1998 \\
\hline & Vigna unguiculata & Guerra and Carvalheira, 1994 \\
\hline & Vigna vexillata & Carvalheira and Guerra, 1998 \\
\hline & Zomicarpa riedeliana & Carvalheira, G.M.G. and Guerra, M., unpublished data \\
\hline
\end{tabular}

In situ hybridization experiments, with isotopic (q.v. Schumann et al., 1990) and non-isotopic markers (q.v. Nenno et al., 1994), have contributed considerably to the characterization of polytenics. These techniques have permitted both the location of many of their DNA sequences and the study of their replication cycle (Brady and Clutter, 1974). For example, the cytolocalization of the ribosomal genes in P. coccineus has been demonstrated by the use of RNAr- $\mathrm{H}^{3}$, revealing RNA puff activity both in satellite pairs and in the heterochromatin of chromosome pairs, without satellites
(Avanzi et al., 1971, 1972; Durante et al., 1977). Isotopic techniques have also made it possible to observe the "extra nucleoli" associated with the telomeres of the polytenics without satellites, suggesting the existence of amplification in this region (Nagl, 1973). Actually, the extra DNA synthesis in the polytenics of the Phaseolus suspensor occurs at the beginning of embryogenesis and not simultaneously with the endoreduplication cycles (Avanzi et al., 1970). Such gene amplification can occur both in the ribosomal cistrons and other regions of the genome and involves some polytene 
chromosome chromatids (Cremonini and Cionini, 1977). Some of these amplified regions are released from the polytenics to form micronucleoli. According to Avanzi et al. (1971), the micronucleoli are composed of a spherical mass of ribonucleoprotein covered by a layer of DNA. These micronucleoli seem to be associated with the intense metabolism of the suspensor basal cells (Nagl, 1973).

With advances in the fluorescence in situ hybridization technique (FISH), several other sequences have been located in plant polytene chromosomes. The first genic sequence hybridized in polytenics was that of the phaseolin group (Schumann et al., 1990; Nenno et al., 1993, 1994). This gene encodes the main seed storage protein of Phaseolus species. In these papers, it was demonstrated that the phaseolin gene seems to be located in chromosome 7 of $P$. coccineus. Another gene that has been located in the polytenics of $P$. vulgaris is the PGIP gene which encodes for polygalacturonase-inhibiting protein, a cell wall protein that specifically inhibits fungal endopolygalacturonases that are important during the early stages of plant pathogenesis. The PGIP gene has been located in a single region of the pericentromeric heterochromatin of the chromosome pair X, next to the euchromatin (Frediani et al., 1993).

The FISH technique as applied in polytene chromosomes has also been a useful tool to study gene evolution. Nagl (1991) hybridized telomeric DNA and the aromatase gene sequence (both from human genome) in $P$. coccineus and $P$. vulgaris polytenics. The results showed that these sequences also hybridize with plant chromosomes, supporting the hypothesis of the evolutionary conservation of important coding or non-encoding sequences throughout living organisms.

\section{POLYTENE CHROMOSOMES OF ANTHER TAPETUM}

Polytene chromosomes are also observed in other plant tissues, of which the anther tapetum tissue has made valuable contributions to the understanding of polytenics in angiosperms. This tissue is widely conserved, being found in groups ranging from bryophytes to angiosperms (Pacini and Franchi, 1993).

The tapetum is the innermost layer of the anther wall in close contact with the pollen grains (Figure 1c). It is generally composed of a simple layer of cells, characterized by the presence of dense cytoplasm and quite a welldeveloped nucleus (Echlin, 1971). During the differentiation of the tapetum, the cells increase both their cytoplasmatic and nuclear volume and then undergo autolysis and degenerate (Mascarenhas, 1990). The tapetum's function seems to be related to the maturation of pollen grain, with biochemical and cytological studies demonstrating the intense metabolic activity in its cells at the end of the tetrad stage and during exine formation (Rowley, 1993).

Until recently, most of the information on the nuclear development of the tapetal cells has come from studies of anther ontogenesis, based on histological analyses by optical or electronic microscopy. Cytological analyses in tapetum were done mainly by Cooper (1933), Brown (1949), Oksala and Therman (1977), Franceschi and Horner (1979), and D'Amato $(1984,1989)$. However, cytogenetical analysis of the tapetal cells of Vigna species has revealed that this tissue can present very peculiar characteristics (Guerra and Carvalheira, 1994). Anther tapetum cells are characterized by the presence of endomitotic or endoreduplication cycles (Cooper, 1933; D'Amato, 1984, 1989; Malallah et al, 1996). In species where the tapetum layer is composed of mononucleate cells, the increase in DNA content is generally a consequence of several endoreduplication cycles, while in species with bi- or multinucleate cells in the tapetum it is the endomitotic cycle which is responsible. In spite of the endoreduplication cycle producing mononucleate cells, tapetal binucleate cells with polytene nuclei have sometimes been observed (Carvalheira and Guerra, 1994).

In general, at the beginning of meiosis, the tapetal cells are mononucleate and diploid. During the tapetal differentiation, three cellular types can be observed, i.e. multinucleate cells, with more than one diploid nucleus (Malallah et al., 1996), mononucleate cells, with a single polyploid nuclei (Carvalheira, G.M.G. and Guerra, M., unpublished data), and mono- or binucleate cells, with one or two polytene nuclei (Carvalheira and Guerra, 1994). In each of these cases, the DNA content per cell is often increased, suggesting that this tissue needs several copies of most genes to supply specific substances for exine development and consequent pollen grain maturation.

The increase in the ploidy level is probably caused either by suppression of anaphase movement (producing a "dumbbell"-shaped polyploid interphase nucleus) or by the occurrence of endomitotic cycles (D'Amato, 1989), while the increase in the number of nuclei per cell is due to the occurrence of one or more mitosis cycles without cytokinesis, resulting in multinucleate cells. Polytene nuclei, on the other hand, are formed through the endoreduplication cycles, and could remain in the interphase stage until the $S$ phase, or progress to the prophase stage and return to a new $\mathrm{G}_{1}$ phase (Guerra and Carvalheira, 1994).

Analysis of both ploidy level and nuclear structures in tapetal cells in genera of several subfamilies has revealed that their chromatin structure may be constant at the genus level. In the family Scrophulariaceae, for example, some species of the genera Pedicularis and Melampyrum have tapetal cells with tetraploid nuclei, in the post-meiotic period. On the other hand, in this same family, the genera Odontetis, Euphrasia and Bellardia have nuclei with enormous chromocenters, but with the same ploidy level (Greilhuber, 1974).

Like the other plant tissue with polytene chromosomes, anther tapetum cells can display polytenics that vary in structure and morphology from species to species (q.v. 
Nagl, 1974, 1981; Carvalheira and Guerra, 1994, 1998). For example, polytene nuclei in the antipodes of Papaver rhoeas were classified by Nagl (1981) into four different types, i.e., nuclei with chromocenters associated with radial chromatin bundles; decondensed nuclei with isolated chromatin fibers; nuclei with condensed chromatin, and nuclei with polytenics proper. Similar variation was found in suspensor cells of Phaseolus embryos, where the polytenics sometimes had granular or fibril form, depending on the degree of contraction in the interchromomeres (Nagl, 1978).

According to Carvalheira and Guerra (1998), the chromatin structure of the polytene nuclei in tapetal cells may basically be divided into three different types:

1. Individualized polytene chromosomes whose chromatin bundles are heteropycnotic in the proximal region and dispersed in the distal region (Figure 1d), characteristic of Phaseolus coccineus, P. vulgaris (Carvalheira and Guerra, 1994), Vigna unguiculata (Guerra and Carvalheira, 1994; Carvalheira and Guerra; 1998), V. umbellata, V. radiata (Carvalheira and Guerra, 1998), Lathyrus and Sesbania marginata.

2. Polytene nuclei with chromocenters associated with the chromatin bundles (Figure 1e), found in most of the species analyzed, including Arachis hypogeae, Caesalpinea echinata, Clitoria cajanifolia, Crotalaria retusa, in three Habenaria species, Luffa cylindrica, Macroptilium peduncularis, two Phaseolus species (Carvalheira and Guerra, 1994), Pithecellobium dulce, Pisum sativum, Sophora tomentosa, Tropaeolum majus and Zomicarpa riedeliana.

3. Polytene nuclei with chromocenters unassociated with chromatin bundles (Figure 1f), a less frequent type, characteristic of Genipa americana, Indigofera hirsuta, Lupinus polyphyllus, Vigna vexillata (Carvalheira and Guerra, 1998) and Vicia sp.

Of these three types of chromatin organization, only the first is ideal for karyological analyses. The polytenics of this group is generally individualized and condensed. This type of chromatin organization has allowed good chromosome spreads to be obtained, facilitating the chromosome counting. In most Phaseolus and Vigna species analyzed that had this type of organization, it was possible to observe all 22 chromosomes of the karyotype (q.v. Guerra and Carvalheira, 1994; Carvalheira and Guerra, 1994).

Although this type of chromatin organization seems to be ideal for karyological analyses, these polytene chromosomes are somewhat smaller than those observed in the embryo suspensor of Phaseolus or those of some other genera (compare Figure $1 b$ and d). The largest polytenics of the anther tapetal cells (observed in Vigna unguiculata) are about 3.5 times bigger than the mitotic ones (Guerra and Carvalheira, 1994). The difference in size observed between polytenics of the embryo suspensor and anther tapetum is probably related to the number of endoreduplicated cells present in each of these tissues. As was men- tioned previously, only a few basal cells undergo many endoreduplication cycles in the embryo suspensor tissue (Nagl, 1981), while in the anther tapetum hundreds of cells undergo this process. The low level of chromatin endoreduplication associated with a large number of cells seems to satisfy the metabolic necessities of both the anther tapetum and microspores. On the other hand, in the giant cell of the embryo suspensor, many endoreduplication cycles seem to be necessary to maintain the perfect functional and nutritional stage of the embryo, most of whose nutrients are supplied by the suspensor cell.

Although the polytenics of the anther tapetum are reduced in size, they have helped in the cytolocalization of DNA sequences. The first in situ hybridization in tapetal polytenics has revealed interesting data different from that which was observed in the polytene chromosomes of the embryo suspensor (Guerra and Kenton, 1996). As stated earlier, after in situ hybridization with the human telomere DNA probe, Nagl (1991) observed that the embryo suspensor polytenics of Phaseolus show a group of dots or compact bands at the telomeres. However, when synthetic telomere oligomers were hybridized with tapetum polytenics in an amphidiploid hybrid of Phaseolus, the oligo was preferentially located at, or close to, the chromocenters. These fluorescent areas were distributed randomly in the nuclear area, although association with the nuclear boundary was never observed (Guerra and Kenton, 1996). This may suggest that, at least in some aspects, the basic molecular organization of diploid nuclei in the anther tapetum is not completely conserved after the endoreduplication cycles. In fact, the loss of telomere association with the nuclear membrane has been documented in some special chromosome types, such as pigeon lampbrush chromosomes (Solovei and Macgregor, 1995) and Diptera polytenic chromosomes (Agar and Sedat, 1983). In plant polytene nuclei, however, this loss of telomeric association with the nuclear envelope was reported for the first time in anther tapetum polytenics (Guerra and Kenton, 1996).

These chromosomes have also helped in the identification of the $45 \mathrm{~S}$ ribosomal sites in Phaseolus coccineus and Vigna unguiculata (Guerra et al., 1996), and 5S sites, in $V$. radiata and $V$. unguiculata (Carvalheira et al., 1998). In P. coccineus, six ribosomal sites were observed in tapetal cells, as has been reported previously (see Avanzi et al., 1972; Durante et al., 1977). Surprisingly, however, ten ribosomal sites were observed in $V$. unguiculata tapetum polytenics (Guerra et al., 1996), instead of one or two pairs as earlier reported (Frahm-Leliveld, 1965; Barone and Saccardo, 1990; Galasso et al., 1992). The large number of ribosomal sites observed in $V$. unguiculata when compared with Phaseolus has suggested that this increase in ribosomal sites may have been initiated by genetic mechanisms, such as gene conversion. According to Guerra et al. (1996), the variation in the number of rDNA sites observed between species of related taxa could be due to the differ- 
ential amplification and fixation of rDNA sequences at different chromosomal sites. On the other hand, four $5 \mathrm{~S}$ ribosomal sites were observed in V. radiata and $V$. unguiculata (Carvalheira et al., 1998), confirming the previous reports for $V$. unguiculata (Galasso et al., 1995), although these reports were first published for $V$. radiata.

In conclusion, although the polytenics of the anther tapetum are smaller than those in suspensor cells, both the large number of polytene cells in this tissue and their structural polytene morphology make these chromosomes more convenient for the study of plant polyteny and chromosome organization. Guerra and Carvalheira (1994) and Carvalheira and Guerra $(1994,1998)$ have suggested that such chromosomes present cycles of diffuse and condensed stages. The change from diffuse to condensed stage seems to depend on the endoreduplication level, genetic background and environmental factors. All these observations suggest that bundled polytene chromosomes of plants, at least in tapetal cells, are most probably the consequence of advanced endoreduplication cycles resulting in prophase or prophase-like chromosomes that may still be able to perform some DNA and RNA synthesis (Brady and Clutter, 1974; Cionini et al, 1982).

\section{ACKNOWLEDGMENTS}

I would like to thank my colleagues Andrea Pedrosa, Marcelo Guerra and Reginaldo de Carvalho for considerable help in preparing the manuscript. This study was supported by grants and fellowships from $\mathrm{CNPq}$ (Conselho Nacional de Desenvolvimento Científico e Tecnológico) and FACEPE (Fundação de Amparo à Ciência e Tecnologia do Estado de Pernambuco).

\section{REFERENCES}

Agar, D.A and Sedat, J.W. (1983). Three-dimensional architecture of a polytene nucleus. Nature 302: 676-681.

Alpi, A., Tognoni, F. and D'Amato, F. (1975). Growth regulator levels in embryo and suspensor of Phaseolus coccineus at two stages of development. Planta 127: 153-162.

Ammermann, D. (1971). Morphology and development of the macronuclei of the ciliates Stylonychia mytilus and Euplotes aediculatus. Chromosoma 33: 209-238.

Ammermann, D., Steinbrüek, G., Berger, L. von and Hennig, W. (1974). The development of the macronucleus in the ciliated protozoan Stylonychia mytilus. Chromosoma 45: 401-429.

Ashburner, M. (1970). Function and structure of polytene chromosomes during insect development. Adv. Insect Physiol. 1: 1-95.

Avanzi, S., Cionini, P.G. and D'Amato, F. (1970). Cytochemical and autoradiographic analysis on the embryo suspensor cells of Phaseolus coccineus. Caryologia 23: 605-638.

Avanzi, S., Nardelle, M.B., Cionini, P.G. and D'Amato, F. (1971). Cytological localization of molecular hybrids between rRNA and DNA in the embryo suspensor cells of Phaseolus coccineus. Accad. Naz. Lincei. Rend. Cl. Sci. Fis. Mat. Nat. Ser. VIII 50: 357-361.

Avanzi, S., Durante, M., Cionini, P.G. and D'Amato, F. (1972). Cytological localization of ribosomal cistrons in polytene chromosomes of Phaseolus coccineus. Chromosoma 39: 191-203.

Barone, A. and Saccardo, F. (1990). Pachytene morphology of cowpea chromosomes. In: Cowpea genetic resource (Ng, N.Q. and Monti, L.M., eds.) International Institute of Tropical Agriculture, Nigeria, pp. 137-143.

Brady, T. (1973a). Cytological studies on the suspensor polytene chromo- somes of Phaseolus: DNA content and synthesis, and the ribosomal cistrons. Caryologia 25: 233-259.

Brady, T. (1973b). Feulgen cytophotometric determination of the DNA content of the embryo proper and suspensor cells of Phaseolus coccineus. Cell Differ. 2: 65-67.

Brady, T. and Clutter, M.E. (1974). Structure and replication of Phaseolus polytene chromosomes. Chromosoma 45: 63-79.

Brodsky, U.Ya. and Uryvaeva, I.V. (1985). Genome Multiplication in Growth and Development Biology of Polyploid and Polytene Cells. University Press, Cambridge.

Brown, S.W. (1949). Endomitosis in the tapetum of tomato. Am. J. Bot. 36 703-716.

Carvalheira, G. and Guerra, M. (1994). The polytene chromosomes of anther tapetum of some Phaseolus species. Cytologia 59: 211-217.

Carvalheira, G. and Guerra, M. (1998). The polytene chromosomes of tapetal cells in the anther of some Vigna Savi cultivars and species. Cytobios 94: 161-168.

Carvalheira, G., Pedrosa, A. and Guerra, M. (1998). The 5s rDNA sites in mitotic and polytene chromosomes of Vigna unguiculata (L.) Walp. and $V$. radiata $(\mathrm{L}$.) Wilczek revealed by in situ hybridization. Cytogenet. Cell Genet. 81: 107.

Cavallini, A., Cionini, P.G. and D'Amato, F. (1981). Location of Heitz's Zerstaubungsstadium (Dispersion Phase) in the mitotic cycle of Phaseolus coccineus and the concept of angiosperm endomitosis. Protoplasma 109: 403-414.

Cionini, P.G. (1987). The suspensor and its role in embryo development in Phaseolus (Papilionaceae): A review. Atti Soc. Toscana Sci. Nat. 94: 151-161.

Cionini, P.G., Bennici, A., Alpi, A. and D'Amato, F. (1976). Suspensor, gibberellin and in vitro development of Phaseolus coccineus embryos. Planta 131: 115-117.

Cionini, P.G., Cavallini, A., Cosi, R. and Fogli, M. (1982). Comparison of homologous polytene chromosomes in Phaseolus coccineus embryo suspensor cells: morphological, autoradiographic and cytophotometric analyses. Chromosoma 86: 386-396.

Clutter, M.E. and Sussex, I.M. (1969). Polytene and continued DNA synthesis in the embryo of the bean Phaseolus coccineus. Ann. Embryol. Morphol. I: 279.

Clutter, M.E., Brady, T., Walbot, V. and Sussex, I.M. (1974). Macromolecular synthesis during plant embryogeny. J. Cell Biol. 63: 1097-1102.

Cooper, D.C. (1933). Nuclear division in the tapetal cells of certain angiosperms. Am. J. Bot. 20: 358-364.

Corsi, G. (1972). The suspensor of Eruca sativa Miller (Cruciferae) during embryogenesis in vitro. G. Bot. Ital. 106: 41-54.

Corsi, G., Renzoni, G.C. and Viegi, L.A. (1973). DNA cytophotometric investigation on the suspensor of Eruca sativa Miller. Caryologia 26: 531-540.

Cremonini, R. and Cionini, P.G. (1977). Extra DNA synthesis in embryo suspensor cells of Phaseolus coccineus. Protoplasma 91: 303-313.

D'Amato, F. (1964). Endopolyploidy as a factor in plant tissue development. Caryologia 17: 41-52.

D'Amato, F. (1984). Role of polyploid in reproductive organs and tissues. In: Embryology of Angiosperms (Johri, B.M., ed). Springer-Verlag, Berlin, pp. 519-566.

D'Amato, F. (1989). Polyploidy in cell differentiation. Caryologia 42: 183211

Durante, M., Cionini, P.G., Avanzi, S., Cremonini, R. and D'Amato, F. (1977). Cytological localization of the genes for the four classes of ribosomal RNA (25S, 18S, 5,8S and 5S) in polytene chromosomes of Phaseolus coccineus. Chromosoma 60: 269-282.

Echlin, P. (1971). The role of the tapetum during microsporogenesis of angiosperms. In: Pollen: Development and Physiology (HeslopHerrison, J., ed.). Butherworths, London, pp. 41-61.

Enzenberg, U. (1961). Beiträge zur Karyologie des Endosperms. Östern. Bot. Z 108: 245-285.

Esau, K. (1974). O embrião. In: Esau, K. Anatomia das Plantas com Sementes. Edgard Blucher, São Paulo, pp. 293.

Fanceschi, V.R. and Horner, H.T. (1979). Nuclear condition of anther tapetum of Ornithogalum caudatum during microsporogenesis. Cytobiologie 18: 413-421.

Frahm-Leliveld, J.A. (1965). Cytological data on some wild tropical Vigna 
species and cultivars from cowpea and asparagus bean. Euphytica 14:251-270.

Frediani, M., Cremonini, R., Salvi, G., Caprari, C., Desiderio, A., D'Ovidio, R., Cervone, F. and Lorenzo, G. de (1993). Cytological localization of the PGIP genes in the embryo suspensor cells of Phaseolus vulgaris L. Theor. Appl. Genet. 87: 369-373.

Freed, H.J. and Grant, W.F. (1976). Polytene chromosome in the suspensor cells of Lotus (Fabaceae). Caryologia 29: 387-390.

Galasso, I., Pignone, D. and Perrino, P. (1992). Cytotaxonomic studies in Vigna I. General technique and Vigna unguiculata C-banding. Caryologia 45: 155-161.

Galasso, I., Schimidt, T., Pignone, D. and Heslop-Herrison, J.S. (1995) The molecular cytogenetics of Vigna unguiculata (L.) Walp.: The physical organization and characterization of $18 \mathrm{~S}-5,8 \mathrm{~S}-25 \mathrm{~S}$ rRNA genes, 5S rRNA genes, telomere like sequences and a family of centromeric repetitive DNA sequences. Theor. Appl. Genet. 91: 928-935.

Gostev, A. and Asker, S. (1978). Polytene chromosomes in globular hair of Salvia horminum (Brown, 1949). Hereditas 88: 133-135.

Greilhuber, J. (1974). Uncommon karyological features in the anther tapetum of some Pedicularieae (Scrophuriaceae). Caryologia 27: 169-181.

Guerra, M. (1988). Os ciclos endomitóticos e os cromossomos politênicos. In: Introdução à Citogenética Geral (Guerra, M.S., ed.). Editora Guanabara, Rio de Janeiro, pp. 36-44.

Guerra, M. and Carvalheira, G. (1994). Occurrence of polytene chromosomes in the anther tapetum of Vigna unguiculata L. (Walp.). J. Hered. $85: 43-46$.

Guerra, M. and Kenton, A. (1996). Distribution of telomere DNA in mitotic and polytene nuclei of the anther tapetum of a tetraploid hybrid bean, Phaseolus vulgaris $\mathrm{x}$ P. acutifolius. Braz. J. Genet. 19: 313-318.

Guerra, M., Kenton, A. and Bennett, M. (1996). rDNA sites in mitotic and polytene chromosomes of Vigna unguiculata (L.) Walp. and Phaseolus coccineus $\mathrm{L}$. revealed by in situ hybridization. Ann. Bot. 78: 157-161.

Lorenzi, R., Bennici, A., Cionini, P.G., Alpi, A. and D'Amato, F. (1978). Embryo-suspensor relations in Phaseolus coccineus: Cytokinins during seed development. Planta 143: 59-62.

Malallah, G.A., Afzal, M., Attia, T.A. and Abraham, D. (1996) Tapetal cell nuclear characteristics of Kuwaiti plants. Cytologia 61: 259-267.

Marks, G.E. and Davies, D.R. (1979). The cytology of cotyledon cells and the induction of giant polytene chromosomes in Pisum sativum. Protoplasma 101: 73-80.

Mascarenhas, J.P. (1990). Gene activity during pollen development. Ann. Rev. Plant Physiol. Plant Mol. Biol. 41: 317-338.

Nagl, W. (1967). Die Riesenchromosomen von Phaseolus coccineus L.: Baueigentümlichkeiten, Strukturmodifikationen, zusätzliche Nukleolen und Vergleich mit den mitotische Chromosome. Osterr. Bot. Z. 114: 171-182.

Nagl, W. (1969a). Banded polytene chromosomes in the legume Phaseolus vulgaris. Nature 221: 70-71.

Nagl, W. (1969b). Correlation of structure and RNA synthesis in the nucleolus-organizing polytene chromosomes of Phaseolus vulgaris. Chromosoma 28: 85-92.

Nagl, W. (1969c). Puffing of polytene chromosomes in a plant (Phaseolus vulgaris). Naturwissenschaften 56: 221-222.

Nagl, W. (1970a). Inhibition of polytene chromosome formation in Phaseolus by polyploid mitosis. Cytologia 35: 252-258.

Nagl, W. (1970b). The mitotic and endomitotic nuclear cycle in Allium cariantum. II. Relations between DNA replication and chromatin structure. Caryologia 23: 71-78.

Nagl, W. (1972). Molecular and structural aspects of the endomitotic chromosome cycle in angiosperm. Chromosomes Today 3: 17-23.

Nagl, W. (1973). Origin and fate of the micronucleoli in the giant cells of the Phaseolus suspensor. Nucleus XVI: 100-109.
Nagl, W. (1974) The Phaseolus suspensor and its polytene chromosomes. Z. Pflanzenernaehr. Bodenkd. 73: 1-44.

Nagl, W. (1976). The polytenic antipodal cells Scilla bifolia: DNA replication pattern and possibility of nucleolar DNA amplification. Cytobiologie 14: 165-170.

Nagl, W. (1978). Endopolyploidy and Polytene in Differentiation and Evolution. North-Holland Publishing, Amsterdam.

Nagl, W. (1981). Polytene chromosomes of plants. Int. Rev. Cytol. 73: 21-53.

Nagl, W. (1985). Chromosomes in differentiation. In: Chromosome and Cell Genetics (Sharma, A.K. and Sharma, A., eds.). Gordon and Breach Science Publishers, New York, pp. 134-172.

Nagl, W. (1987). Genetics. I. Replication. Prog. Bot. 49: 181-188.

Nagl, W. (1991). Two human DNA sequences (aromatase, telomere) detected in Phaseolus (Fabaceae) by respective blot and in situ hybridization. Pol. Bot. Stud. 2: 159-164

Nagl, W., Pohl, J. and Radler, A. (1985). The DNA endoreduplication cycles. In: The Cell Division Cycle in Plant (Bryant, J.A. and Francis, D., eds). University Press, Cambridge, pp. 217-232.

Nenno, M., Schumann, K. and Nagl, W. (1993). Mapping phaseolin genes to polytene chromosomes by in situ hybridization (FISH). Ann. Rep. Bean Impr. Coop. 36: 3-4.

Nenno, M., Schumann, K. and Nagl, W. (1994). Detection of rRNA and phaseolin genes on polytene chromosomes of Phaseolus coccineus by fluorescence in situ hybridizations after pepsin pretreatment. Genome 37: 1018-1021.

Oksala, T. and Therman, E. (1977). Endomitosis in tapetal cells of Eremurus (Liliaceae). Am. J. Bot. 64: 866-872.

Pacini, E. and Franchi, G. (1993). Role of the tapetum in pollen and spore dispersal. Plant Syst. Evol. 7: 1-11.

Painter, T. and Reindorp, E. (1939). Endomitosis in the nurse cells of the ovary of Drosophila melanogaster. Chromosoma 1: 276-283.

Rowley, J.R. (1993). Cycles of hyperactive in tapetal cells. Plant Syst. Evol. 7: 23-37.

Schulz, S.P. and Jensen, W.A. (1969). Capsella embryogenesis: The suspensor and basal cell. Protoplasma 67: 139-163.

Schumann, K., Baumann, A. and Nagl, W. (1990). Localization of phaseolin genes in the polytene chromosomes of Phaseolus coccineus (Leguminoseae). Genetica 83: 73-76

Schweizer, D. (1976). Giemsa and fluorochrome banding of polytene chromosomes in Phaseolus vulgaris and P. coccineus. In: Current Chromosome Research (Jones, K. and Brandham, P.E., eds.). Elsevier, Amsterdam, pp. 51-56.

Schweizer, D. and Ambros, P. (1979). Analysis of nucleolus organizer regions (NORs) in mitotic and polytene chromosomes of Phaseolus coccineus by silver staining and Giemsa C-banding. Plant Syst. Evol. 132: 27-51.

Sen, S. (1980). Evidence of coiling cycle in polytenic chromosome of suspensor cell. Nucleus 23: 88-89.

Shang, X.M. and Wang, W.C. (1991). DNA amplification, chromatin variations, and cells of commom bread wheat in vitro and roots of regenerated plants in vivo. Genome 34: 799-809.

Solovei, I. and Macgregor, H. (1995). Star-like complexes of chromosomes in the diplotene oocytes of pigeon. Chromosome Res. 3: 62.

Therman, E. and Murashige, T. (1984). Polytene chromosomes in cultivated pea roots (Pisum, Fabaceae). Plant Syst. Evol. 148: 25-33.

Viegi, L., Pagni, A.M., Corsi, G. and Renzoni, G.C. (1976). Il sospensore embrionale nelle Cruciferae. I. Morfologia e struttura. G. Bot. Ital. 110: 347-357.

Walbot, V., Brady, T., Clutter, M. and Sussex, I. (1972). Macromolecular synthesis during plant embryogeny: Rates of RNA synthesis in Phaseolus coccineus embryos and suspensors. Devel. Biol. 29: 104111 